\title{
Chitosan/Carboxymethylcellulose/Ionic Liquid/Ag(0) Nanoparticles Form a Membrane with Antimicrobial Activity
}

\author{
Camila Quadros, ${ }^{1}$ Vinícius W. Faria, ${ }^{1}$ Manuela P. Klein, ${ }^{2}$ \\ Plinho F. Hertz, ${ }^{2}$ and Carla W. Scheeren ${ }^{1}$ \\ ${ }^{1}$ Laboratory of Physical Chemistry, School of Chemistry and Food, Universidade Federal do Rio Grande (FURG), \\ Avendia Itália Km 08, 96201-900 Rio Grande do Sul, RS, Brazil \\ ${ }^{2}$ Institute of Science and Food Technology, Universidade Federal do Rio Grande do Sul (UFRGS), \\ Rio Grande do Sul, RS, Brazil
}

Correspondence should be addressed to Carla W. Scheeren; cwscheeren@hotmail.com

Received 22 January 2013; Accepted 7 February 2013

Academic Editor: Benjaram M. Reddy

Copyright (C) 2013 Camila Quadros et al. This is an open access article distributed under the Creative Commons Attribution License, which permits unrestricted use, distribution, and reproduction in any medium, provided the original work is properly cited.

Silver metal nanoparticles were immobilized in chitosan/carboxymethylcellulose/BMI.BF 4 (1- $n$-butyl-3-methylimidazolium tetrafluoroborate ionic liquid) $(\mathrm{CS} / \mathrm{CMC} / \mathrm{IL})$ to form polymeric membrane with $20 \mu \mathrm{m}$ thickness. The CS/CMC/IL polymeric membrane was prepared using a simple solution blending method. Irregularly shaped $\operatorname{Ag}(0)$ nanoparticles with monomodal size distributions of $8.0 \pm 0.4 \mathrm{~nm} \operatorname{Ag}(0)$ were immobilized in the membrane. The presence of small $\operatorname{Ag}(0)$ nanoparticles induced an augmentation in the CS/CMC/IL film surface areas. The CS/CMC/IL membrane containing $\mathrm{Ag}(0)$ showed increase antimicrobial activity the $\operatorname{Ag}(0)$ concentration increased up to saturation at $10 \mathrm{mg}$. CS/CMC/IL membrane that contains $\operatorname{Ag}(0)$ nanoparticles has enhanced durability of the membrane and exhibited stronger antimicrobial activity against Escherichia coli and Staphylococcus aureus.

\section{Introduction}

Metal nanoparticles are known to incapacitate microbes by interacting with their enzymes, proteins, and/or DNA to inhibit cell proliferation or cell division. For these applications, nanoparticles have to be supported in biocompatible polymer systems in various forms (e.g., catheters, dental material, medical devices and implants, and burn dressings). This combination can form semipermeable membranes to protect against microbial contamination [1]. The antibacterial properties of composites have been well studied [2-6] and they exhibit a stronger toxicity towards bacteria than other organisms, ranging from fungi to the human immune system $[7,8]$. For biomedical applications, polymers are well studied. Cellulose acetate is a good candidate because this polymer is hydrophilic, nontoxic, biodegradable, and renewable with good processability [9-11]. For example, cellulose diacetate semipermeable membrane embodying noble metal nanoparticles $(\mathrm{Au}$ and $\mathrm{Pt}$ ) has been prepared [12]. Polypropylene (PP) is a polymer which has good mechanical properties and has many medical applications, such as tissue replacement and organ wall reconstructions [13-17]. However, to obtain a wider medical application, nanoparticles can be embedded [17]. The synthesis, spectroscopic characterization, and antimicrobial efficiency of gold and silver nanoparticles embedded amphiphilic comb-type graft copolymers having good film-forming properties have been studied [18]. The cotton fabric was used to support Ag nanoparticles $(41 \pm 7 \mathrm{~nm}$ in diameter and content of $0.53 \mathrm{wt} \%$ ) to obtain an antimicrobial effect on both grampositive (Staphylococcus aureus) and gram-negative bacteria (Escherichia coli) [19]. Indeed, we report herein that the combination of silver [20] nanoparticles with mesoporous chitosan/carboxymethylcellulose/ionic liquid blend membranes generates new membrane-supported $\operatorname{Ag}(0)$ nanoparticles with antimicrobial activity. 


\section{Experimental Section}

2.1. General. All reactions involving silver nanoparticles were carried out under an argon atmosphere in modified Fischer-Porter bottles. The halide-free 1-n-butyl-3methylimidazolium tetrafluoroborate $\left(\mathrm{BMI} \mathrm{BF}_{4}\right)$ ionic liquid was prepared according to a known procedure and dried over molecular sieves (4 $\AA$ ). Its purity was checked by ${ }^{1} \mathrm{H}$ NMR using the intensity of the ${ }^{13} \mathrm{C}$ satellites of the imidazolium $\mathrm{N}$-methyl group as an internal standard [21]. Solvents were dried with the appropriate drying agents and distilled under argon prior to use. Chitosan with a degree of deacetylation of $90 \%$ was purchased from Aldrich. Silver oxide (Aldrich), sodium carboxymethylcellulose (Aldrich), and acetone (Merck, 99.8\%) were used to prepare the membranesupported metal. All other chemicals were purchased from commercial sources and used without further purification. The $\operatorname{Ag}(0)$ nanoparticles formations were carried out in a modified Fischer-Porter bottle immersed in a silicone oil bath while connected to a hydrogen tank. The temperature was maintained using a digital controller (ETS-D4 IKA) at $85^{\circ} \mathrm{C}$ for $\operatorname{Ag}(0)$ nanoparticles.

2.2. Synthesis of $A g(0) \cdot B M I \cdot B F_{4}$. In a typical experiment, a Fischer-Porter bottle containing $\mathrm{BMI} \mathrm{BF}_{4}(1 \mathrm{~mL}), \mathrm{Ag}_{2} \mathrm{O}$ $25 \mathrm{mg}(0.11 \mathrm{mmol})$, and $n$-butylimidazole $(80 \mu \mathrm{L}, 0.61 \mathrm{mmol})$ was stirred at room temperature for $15 \mathrm{~min}$ yielding a black dispersion. The system was then heated to $85^{\circ} \mathrm{C}$ and hydrogen ( 4 bar) was admitted to the system. After stirring for $2 \mathrm{~h}$, a black "solution" was obtained. The reactor was evacuated for $1 \mathrm{~h}$ at $100^{\circ} \mathrm{C}$ to remove excess hydrogen and $n$-butylimidazole [20]. The Ag.BMI.BF 4 samples thus obtained were prepared for TEM and X-ray analysis (see the following).

\subsection{Synthesis of a CS/CMC/IL Polymeric Membrane Con-} taining $\mathrm{Ag}(0)$ Nanoparticles. Two grams of chitosan (CS) was dissolved in $100 \mathrm{~mL}$ of a 2 vol\% aqueous acetic acid solution, and $2 \mathrm{~g}$ of sodium carboxymethylcellulose (CMC) was dissolved in $100 \mathrm{~mL}$ of deionized water. Both chitosan and sodium carboxymethylcellulose solutions were filtered to remove trace precipitates before they were mixed. The sodium carboxymethylcellulose solution was added dropwise to the chitosan solution at $60^{\circ} \mathrm{C}$ under stirring. After the complete mixing of the CS and CMC solutions $0.5 \mathrm{~g}$ of $\mathrm{BMI}^{\mathrm{B}} \mathrm{BF}_{4}$, ionic liquid was added, followed by adding $10 \mathrm{mg}$ of $\mathrm{Ag}(0)$ nanoparticles and this was followed by vigorous stirring for uniform dispersion. After $6 \mathrm{~h}$ of stirring, the solution was poured into a poly(ethylene terephthalate) box and allowed to dry in a fume hood overnight at approximately $50^{\circ} \mathrm{C}$ for $48 \mathrm{~h}$. The morphology of the mesoporous CS/CMC/IL/Ag(0) nanoparticles blend membranes was observed with an analysis was performed using a JEOL model JSM 5800 with 10 and $20 \mathrm{kV}$. Both the surface and cross-section (prepared by the fracturing of the membrane under liquid nitrogen) were scanned.

2.4. X-Ray Powder Diffraction Analysis (XRD). The phase structures of the $\mathrm{Ag}(0)$ nanoparticles prepared in $\mathrm{BMI}_{\mathrm{BF}}$ were characterized by XRD. For the XRD analysis, the silver nanoparticles as a fine powder were placed in the sample holder. The XRD experiments were carried out on a Siemens D500 diffractometer equipped with a curved graphite crystal using $\mathrm{Cu}$ Ka radiation $(\lambda=1.5406 \AA)$. The diffraction data were collected at room temperature in a Bragg-Brentano $\theta-2 \theta$ geometry. The equipment was operated at $40 \mathrm{kV}$ and $20 \mathrm{~mA}$ with a scan range between $20^{\circ}$ and $90^{\circ}$. The diffractograms were obtained with a constant step of $\Delta 2 \theta=0.05$. The indexation of Bragg reflections was obtained with a pseudoVoigt profile fitting using the FULLPROF code [22]. For XRD analysis, $40 \mathrm{mg}$ of nanoparticles of $\mathrm{Ag}(0)$ were used.

2.5. Transmission Electron Microscopy Analysis (TEM). TEM was obtained using a JEOL JEM 2010 microscope operating at $200 \mathrm{kV}$ equipped with an EDS system and a JEOL JEM 1200 EXII operating at $120 \mathrm{kV}$. A $20 \mu \mathrm{m}$ objective aperture and slightly underfocused $(\Delta f \approx-300 \mathrm{~nm}$ ) objective lens were used to obtain the bright field TEM images. The morphology and electron diffraction (ED) of the $\operatorname{Ag}(0)$ nanoparticles were analyzed by TEM. The samples were prepared by deposition of the silver nanoparticles in isopropanol at room temperature on a carbon-coated copper grid. The histograms of the nanoparticles size distribution were obtained from measurements of around 300 diameters and were reproduced in different regions of the $\mathrm{Cu}$ grid, assuming a spherical shape. For the analyses of the nanoparticles of $\operatorname{Ag}(0)$ immobilized in the CS/CMC membrane, the material was immobilized in resin and sliced with the technique of ultramicrotomy and placed on a carbon-coated copper grid. For analysis by TEM, $10 \mathrm{mg}$ of nanoparticles of $\operatorname{Ag}(0)$ was used.

\subsection{Scanning Electron Microscopy (SEM) and EDS Elemental} Analysis. The morphology of the polymeric membranes $\mathrm{CS} / \mathrm{CMC} / \mathrm{IL} / \mathrm{Ag}(0)$ nanoparticles and the electron dispersive spectroscopy (EDS) analysis was performed using a JEOL model JSM 5800 with 10 and $20 \mathrm{kV}$ and magnification of 3000-10000x.

2.7. $\mathrm{N}_{2}$ Adsorption-Desorption Isotherms. The specific surface area and pore size distribution of the CS/CMC/IL/Ag(0) polymeric membranes were determined at nitrogen boiling point in a home-made volumetric apparatus with a vacuum line system employing a turbomolecular Edward vacuum pump, operating with temperature of $110^{\circ} \mathrm{C}$ during $2 \mathrm{~h}$. The pressure measurements were made using a capillary $\mathrm{Hg}$ barometer. The specific surface areas of the $\mathrm{CS} / \mathrm{CMC} / \mathrm{IL} / \operatorname{Ag}(0)$ polymeric membranes were determined from the BET multipoint method [23]. The pore size distribution was obtained using the BJH method [23, 24].

2.8. Infrared Analysis (IR). The infrared spectra of the pure CS/CMC polymer films, the CS/CMC polymeric membranes containing $\mathrm{BMI}_{\mathrm{BF}}$, and the $\mathrm{CS} / \mathrm{CMC} / \mathrm{IL}$ polymer films containing the $\operatorname{Ag}(0)$ nanoparticles were obtained using a Shimadzu model 8300 FTIR. The spectra were obtained at room temperature in 100 cumulative scans with a resolution of $4 \mathrm{~cm}^{-1}$. 
2.9. Flame Atomic Absorption (FAAS). Silver present in the $\mathrm{CS} / \mathrm{CMC} / \mathrm{IL} / \mathrm{Ag}(0)$ polymeric membranes was measured using a Perkin-Elmer (Boston, MA, USA) flame atomic absorption spectrometer, model Analyst 200 (FAAS), using an air-acetylene $\left(10: 2.5 \mathrm{~L} \mathrm{~min}^{-1}\right)$ flame under optimized conditions. Hollow cathode lamps of $\mathrm{Ag}(\lambda=338.29 \mathrm{~nm})$ from the same manufacturer were used as radiation sources.

2.10. Antimicrobial Analysis. For the experiments, the preinocula of the Escherichia coli and Staphylococcus aureus samples cultivation by growth on a BHI liquid culture medium in a $5 \mathrm{~mL}$ tube. The cultivation was monitored during $12 \mathrm{~h}$ with agitation at $37^{\circ} \mathrm{C}$, after the time samples were plated on $\mathrm{BHI}$-agar and, to test the antimicrobial activity of the membranes, a procedure based on the disc diffusion principle was followed. The samples were inoculated in the agar plate for a lawn of growth using a swab, which was best accomplished by streaking the plate in one direction, then streaking at right angles to the first streaking, and finally streaking diagonally. Finally, the swab was used to streak the outer perimeter of the agar. Two membrane discs approximately $1.5 \mathrm{~cm}$ in diameter were placed in each plate: a CS/CMC membrane disc containing the ionic liquid $\mathrm{BMI} \mathrm{BF}_{4}(\mathrm{CS} / \mathrm{CMC} / \mathrm{IL}$, as control) and another membrane disc (CS/CMC/IL with $\mathrm{Ag}(0)$ as sample) with the metal nanoparticles. These plates were incubated at $37^{\circ} \mathrm{C}$ for $24 \mathrm{~h}$ and then analyzed for the inhibition of growth (halo).

2.11. Antimicrobial Activity Studies. The antimicrobial activities of freeze-dried CS/CMC/IL/Ag(0) polymer membrane samples cut into $1.5 \mathrm{~cm}$ diameter discs were investigated for representative gram-negative bacteria (E. coli) and grampositive bacteria (S. aureus) using the disc diffusion method.

2.12. The Disc Diffusion Method. These experiments were performed in a Luria-Bertani (LB) medium solid agar Petri dish. The freeze-dried CS/CMC/IL/Ag(0) polymer membrane was cut into a disc shape $1.5 \mathrm{~cm}$ in diameter, sterilized by autoclaving for $15 \mathrm{~min}$ at $120^{\circ} \mathrm{C}$, and placed on either an E. coli-cultured agar plate or a $S$. aureus-cultured agar plate. They were then incubated for $24 \mathrm{~h}$ at $37^{\circ} \mathrm{C}$ and the inhibition zone was monitored.

\section{Results and Discussion}

The CMC is a cellulose derivative that contains a carboxyl group on each polymer unit and is soluble in both neutral and basic media. To make it insoluble, CS is chosen to form a complex with CMC. The functional properties of CMC depend on the degree of substitution of the cellulose structure (i.e., how many of the hydroxyl groups have taken part in the substitution reaction?), as well as the chain length of the cellulose structure and the degree of clustering of the carboxymethyl substituents $[25,26]$. In this study, we also used ionic liquid to cross-link the CS/CMC component in the blend membranes to form a semiinterpenetrating network for further enhancement of the membrane stability, higher flexibility, lower viscosity, and good formability of the

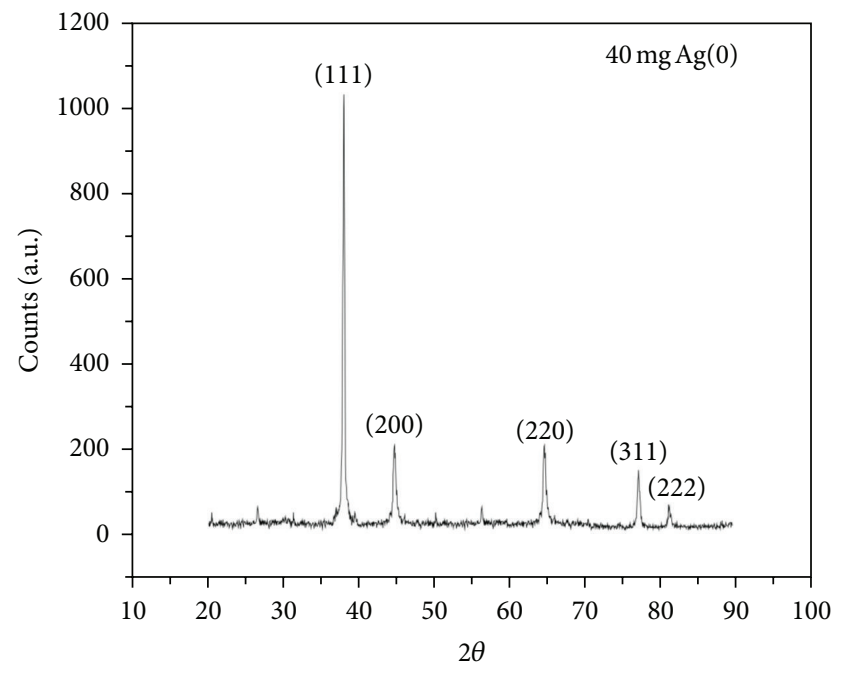

FIgURE 1: X-ray diffraction pattern of $\mathrm{CS} / \mathrm{CMC} / \mathrm{Ag}(0)$ in $\mathrm{BMI}^{-\mathrm{BF}_{4}}$ IL.

polymer film. The $\operatorname{Ag}(0)$ nanoparticles were incorporated in the porous of the polymeric membranes. Several reports have shown that this method can produce porous membranes with high porosity and large pore size [27-33]. The XRD pattern of the $\operatorname{Ag}(0)$ nanoparticles (Figure 1) confirmed a crystalline the mean diameter of $8.9 \pm 2.0 \mathrm{~nm}$, respectively, as estimated by the Debye-Scherrer equation with the full width at halfmaximum (FWHM) of the (111), (200), (220), (311), and (222) planes.

TEM analyses were also performed on the prepared samples. Figure 2(a) shows micrographs of the $\operatorname{Ag}(0)$ nanoparticles. Analysis of the micrographs indicates that the nanoparticles are irregularly shaped, but evaluating their characteristic diameter results in a polydispersion distribution with an average diameter of $8.9 \pm 2.0 \mathrm{~nm}$ for $\operatorname{Ag}(0)$ nanoparticles. We note that these measurements are for samples prepared in the ionic liquid BMI.BF $\mathrm{Br}_{4}$ and estimated from ensembles of 300 particles found in an arbitrarily chosen area of the enlarged micrographs.

The histograms in Figure 2(b) show that particle size distributions can be reasonably well fit by a Gaussian distribution. TEM micrographs of the nanoparticle-embedded membranes in the $\mathrm{BMI}_{\mathrm{BF}}$ IL (Figure 3) show that the metals are distributed all over the membrane. This is a clear indication that the immobilization of the nanoparticles does not significantly change the aggregation and size distribution of the nanoparticles in the BMI.BF IL.

The scanning electron micrographs (SEM) of the crosssections CS/CMC/IL/ $\operatorname{Ag}(0)$ and polymeric films are shown in Figure 4. It is clear that the morphological structure of the films changes with or without the presence of IL. The CS/CMC polymeric membrane (Figure 4(a)) seems to have a scaled structure. In contrast, addition of the IL seems to cause an increase in the microstructural order in the CS/CMC/IL (Figure $4(\mathrm{~b})$ ). This result is in agreement with the general concept that imidazolium IL tends to act as entropic drivers for the formation nanostructured materials $[21,34]$. 


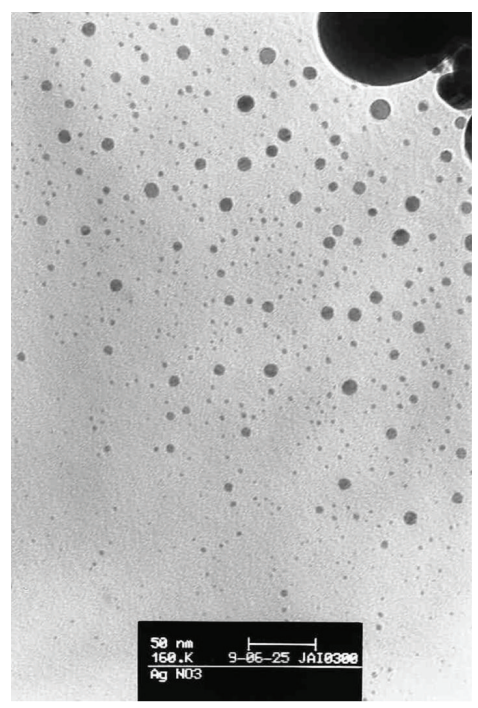

(a)

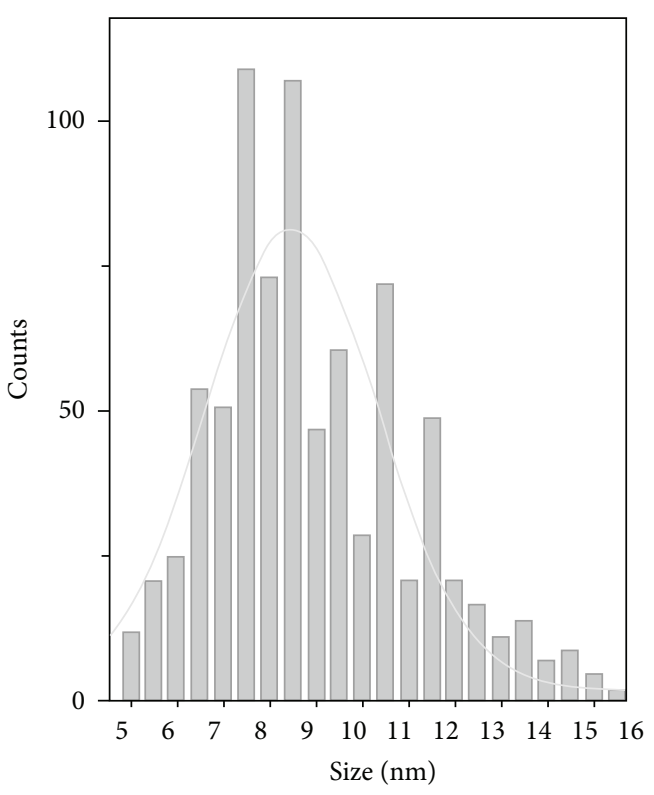

(b)

FIGURE 2: TEM micrographs (a) and histograms (b) showing the particle size distribution of CS/CMC/IL/Ag(0).

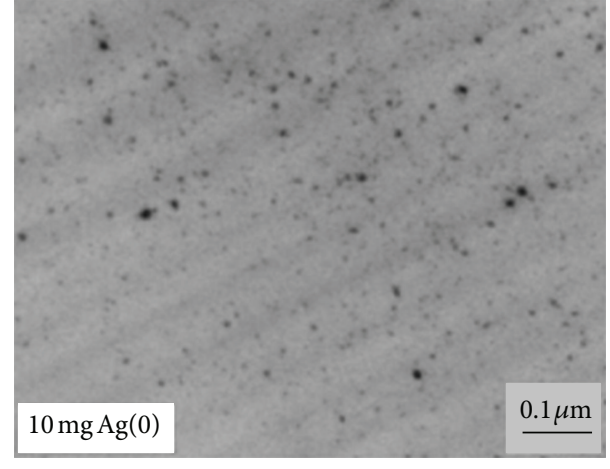

FIGURE 3: TEM micrographs of CS/CMC/IL/Ag(0) polymeric mem-

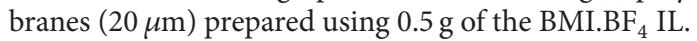

Figure 5 shows that the structure CS/CMC/IL/Ag(0) polymeric membrane exhibits a skin that is relatively porous on the top side and a relatively porous structure over all of the film cross-sections. Figure 6 shows that the sample prepared in the presence of the IL also stains heterogeneously over all of the membrane cross-section, indicating the presence of $\operatorname{Ag}(0)$ nanoparticles (represented by the clear points (BSE method), (Figure 6(a)). In the same figure, the CS/CMC/IL/Ag(0) film cross-section shows that the thickness of the film was about $20 \mu \mathrm{m}$ (Figure 6(b)). EDS analysis for CS/CMC/IL/Ag(0) nanoparticles showed the presence of the metal $(\mathrm{Ag})$ and showed F signals, indicating the presence of the nanoparticles and $\mathrm{BMI}_{\mathrm{BF}}$ in the polymeric membrane.

The surface area studied using $\mathrm{N}_{2}$ adsorption-desorption isotherms at very low relative pressures $\left(P_{i e} / P_{o}\right)$ exhibited high adsorption of the $\mathrm{N}_{2}$, confirming the presence of porous
TABLE 1: Surface areas and pore volumes of the polymeric membranes of pure CS/CMC, CS/CMC/IL, and CS/CMC/IL/Ag(0) membranes.

\begin{tabular}{lcccc}
\hline Polymeric membrane & $\mathrm{M}(0)$ & $\mathrm{CS} / \mathrm{CMC}$ & $\mathrm{IL}$ & $S_{\text {bet }}$ \\
\hline (a) CS/CMC & - & $5 \mathrm{~g}$ & - & $36 \mathrm{~m}^{2} / \mathrm{g} \pm 10 \%$ \\
(b) CS/CMC/IL & - & $5 \mathrm{~g}$ & $0.5 \mathrm{~g}$ & $22 \mathrm{~m}^{2} / \mathrm{g} \pm 10 \%$ \\
(d) CS/CMC/IL/Ag(0) & $10 \mathrm{mg}$ & $5 \mathrm{~g}$ & $0.5 \mathrm{~g}$ & $88 \mathrm{~m}^{2} / \mathrm{g} \pm 10 \%$ \\
\hline
\end{tabular}

structures in the membrane (porous structure was confirmed by SEM analysis in Figure 5). The surface area (Table 1) of the pure CS/CMC membrane was $36 \mathrm{~m}^{2} / \mathrm{g}(10 \%)$ and that of the membrane containing $0.5 \mathrm{~g}$ of the $\mathrm{BMI} \mathrm{BF}_{4}$ ionic liquid was $22 \mathrm{~m}^{2} / \mathrm{g}(10 \%)$, exhibiting a reduction with the addiction of the IL. This information shows that the introduction of the ionic liquid produces an occupation of the free porous arrangement in the polymer membrane, especially in the predominant fraction. In the case of the CS/CMC/IL polymeric membranes containing $10 \mathrm{mg}$ of $\mathrm{Ag}(0)$ nanoparticles, surface areas of $88 \mathrm{~m}^{2} / \mathrm{g}(10 \%)$ were obtained. The presence of small and stable $\operatorname{Ag}(0)$ nanoparticles induces an augmentation in the $\mathrm{CS} / \mathrm{CMC} / \mathrm{IL} / \mathrm{Ag}(0)$ nanoparticles polymeric membrane surface area (compare entries (a), (b), and (c) of Table 1). The nanoparticles are located inside the pores of the membrane; the fact that the surface area increases with the addition of nanoparticles is possibly related to nanometric diameter; decreasing size of the nanoparticles increases the relative surface area and volume enhancing effect of surface. This ratio shows that it is ideal for composite materials, chemical reactions, and energy storage.

The investigation of the silver elemental concentrations in the polymeric membrane samples containing $0.5 \mathrm{~g}$ of $\mathrm{BMI}_{\mathrm{BF}}$ is shown in Table 2. The concentrations of 


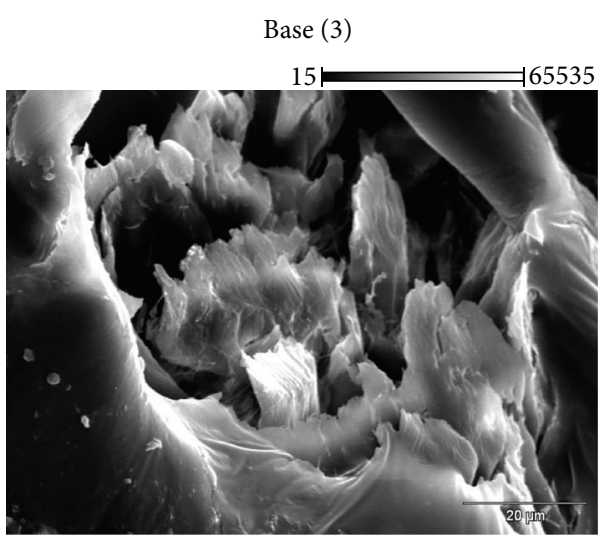

(a)

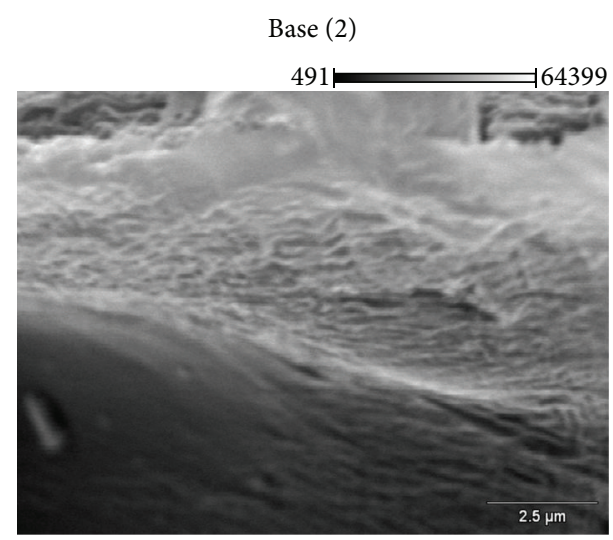

(b)

FIGURE 4: SEM micrographs show that morphological structure of the films changes with (b) or without (a) the presence of IL.

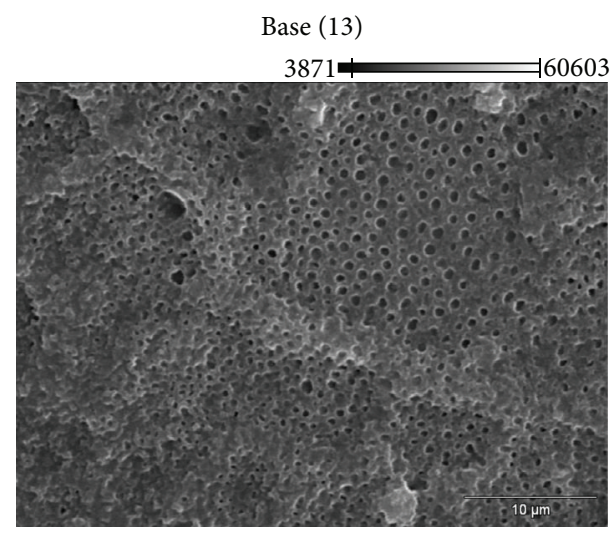

FIGURE 5: SEM micrographs illustrating the porous structure of the $\mathrm{CS} / \mathrm{CMC} / \mathrm{IL}$ polymeric membrane.

TABLE 2: Measured values of silver concentrations in the antimicrobial CS/CMC/IL membrane samples.

\begin{tabular}{lccc}
\hline Entry & Sample & $\begin{array}{c}\mathrm{M}(0) \\
\left(\mu \mathrm{gg}^{-1}\right)\end{array}$ & $\begin{array}{c}\mathrm{M}(0) \\
\%(\mathrm{~m} / \mathrm{m})\end{array}$ \\
\hline 1 & $\mathrm{CS} / \mathrm{CMC} / \mathrm{IL} / \mathrm{Ag}(0) 1 \mathrm{mg}$ & 213 & 0.03 \\
2 & $\mathrm{CS} / \mathrm{CMC} / \mathrm{IL} / \mathrm{Ag}(0) 5 \mathrm{mg}$ & 446 & 0.06 \\
3 & $\mathrm{CS} / \mathrm{CMC} / \mathrm{IL} / \mathrm{Ag}(0) 10 \mathrm{mg}$ & 528 & 0.11 \\
4 & $\mathrm{CS} / \mathrm{CMC} / \mathrm{IL} / \mathrm{Ag}(0) 15 \mathrm{mg}$ & 539 & 0.11 \\
\hline
\end{tabular}

$\operatorname{Ag}(0)$ nanoparticles incorporated in the polymeric membranes were determined using FAAS. The concentrations are expressed as $\mu \mathrm{gg}^{-1}$ and $\%(\mathrm{~m} / \mathrm{m})$ for $\mathrm{Ag}(0)$ nanoparticles at the one thickness, $20 \mu \mathrm{m}$.

Is possible observed that, the amount of metal in the membrane containing $\operatorname{Ag}(0)$ nanoparticles increased with an increase in concentration (compare entries 1-3, Table 2) until saturation was reached (compare entries 3-4, Table 2). The membranes containing $\mathrm{Ag}(0)$ nanoparticles demonstrating the universal characteristic of saturation of the membrane at $10 \mathrm{mg}$ of metal. Figure 7 shows the infrared spectra for the CS/CMC and CS/CMC/IL polymeric membranes. The
TABLE 3: Mechanical properties for samples: CS/CMC, CS/CMC/IL, and $\mathrm{CS} / \mathrm{CMC} / \mathrm{IL} / \mathrm{Ag}(0)$.

\begin{tabular}{lccc}
\hline Entry & Sample & $\begin{array}{c}\text { Young modulus } \\
(\mathrm{MPa})\end{array}$ & $\begin{array}{c}\text { Tension at } \\
\text { break (MPa) }\end{array}$ \\
\hline 1 & $\mathrm{CS} / \mathrm{CMC}$ & $1236 \pm 30$ & $48 \pm 4$ \\
2 & $\mathrm{CS} / \mathrm{CMC} / \mathrm{IL}$ & $32 \pm 3$ & $4 \pm 1$ \\
3 & $\mathrm{CS} / \mathrm{CMC} / \mathrm{IL} / \mathrm{Ag}(0) 10 \mathrm{mg}$ & $92 \pm 10$ & $4 \pm 1$ \\
4 & $\mathrm{CS} / \mathrm{CMC} / \mathrm{IL} / \mathrm{Ag}(0) 5 \mathrm{mg}$ & $24 \pm 5$ & $4 \pm 1$ \\
5 & $\mathrm{CS} / \mathrm{CMC} / \mathrm{IL} / \mathrm{Ag}(0) 1 \mathrm{mg}$ & $32 \pm 3$ & $4 \pm 1$ \\
\hline
\end{tabular}

spectra show differences, which are assigned to different groups content.

The presence of the ionic liquid is confirmed by the stretching of the band at $3170 \mathrm{~cm}^{-1}$ due to the presence of the aromatic C-H group. After impregnation of the ionic liquid in the membrane supports, a significant decrease is observed in the intensity of the $3400 \mathrm{~cm}^{-1}$ band attributed the $-\mathrm{OH}$ and in the intensity $1558 \mathrm{~cm}^{-1}, 1666 \mathrm{~cm}^{-1}$ band attributed the $\mathrm{N}-$ $\mathrm{H}$ stretching of the $\mathrm{CS} / \mathrm{CMC}$, indicating the participation of the $-\mathrm{OH}$ group and $\mathrm{N}-\mathrm{H}$ in the interaction with the anion of the ionic liquid.

Table 3 summarizes the stress-strain test results for the $\mathrm{CS} / \mathrm{CMC}, \mathrm{CS} / \mathrm{CMC} / \mathrm{IL}$, and $\mathrm{CS} / \mathrm{CMC} / \mathrm{IL} / \mathrm{Ag}(0)$ polymeric membrane samples at a constant temperature. The addition of the BMI.BF 4 ionic liquid in the CS/CMC shows a decrease of the Young's modulus for the CS/CMC/IL and $\mathrm{CS} / \mathrm{CMC} / \mathrm{IL} / \mathrm{Ag}(0)$ systems (compare entries 1 and 2 of Table 3).

This reduction in the modulus is probably a result of the plasticizing effect of the ionic liquid (compare entries 1 and $2-5$, Table 3 ). It is clear that the observed modulus values for the $\mathrm{CS} / \mathrm{CMC} / \mathrm{IL} / \mathrm{Ag}(0)$ polymeric membranes depend significantly on the amount of metal (compare entries 3-5, Table 3). The presence of plasticizer substance that gives effect causes an increase in stiffness. 


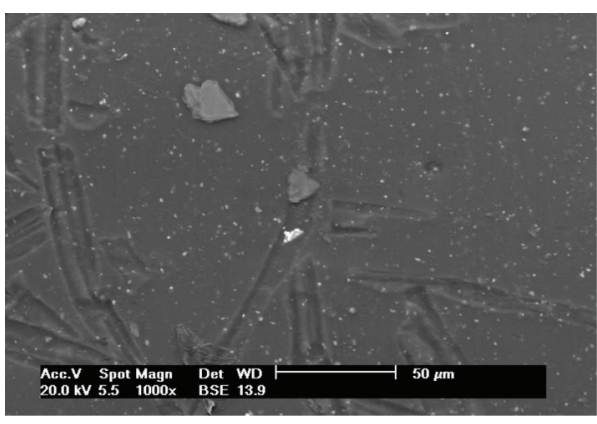

(a)

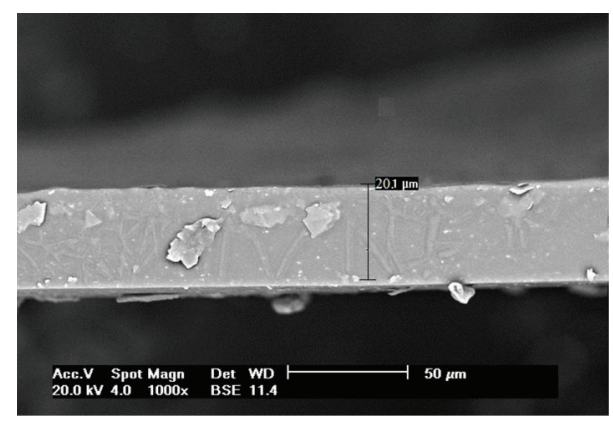

(b)

FIGURE 6: SEM micrographs illustrating the heterogeneous distribution on polymeric films of (a) compact membrane of CS/CMC/IL/Ag(0), (b) showing membrane thickness of CS/CMC/IL/Ag(0).

TABLE 4: The antibacterial activity of CS/CMC/IL/Ag(0) membranes on S. aureus and E. coli as determined by the agar tests.

\begin{tabular}{|c|c|c|c|c|c|}
\hline \multirow{2}{*}{ Entry } & \multirow{2}{*}{ Sample } & \multicolumn{2}{|c|}{ Size of inhibition zone $(\mathrm{mm})$} & \multicolumn{2}{|c|}{ Antibacterial effect } \\
\hline & & S. aureus & E. coli & S. aureus & E. coli \\
\hline 1 & $\mathrm{CS} / \mathrm{CMC} / \mathrm{IL}$ & 0 & 0 & None & None \\
\hline 2 & $\mathrm{IL} / \operatorname{Ag}(0)$ & 1 & 1.5 & Limited & Limited \\
\hline 3 & $\mathrm{CS} / \mathrm{CMC} / \mathrm{IL} / \mathrm{Ag}(0) 1 \mathrm{mg}$ & 2 & 5 & Limited & Good \\
\hline 4 & $\mathrm{CS} / \mathrm{CMC} / \mathrm{IL} / \mathrm{Ag}(0) 5 \mathrm{mg}$ & 4 & 5 & Good & Good \\
\hline 5 & $\mathrm{CS} / \mathrm{CMC} / \mathrm{IL} / \mathrm{Ag}(0) 10 \mathrm{mg}$ & 4 & 5 & Good & Good \\
\hline
\end{tabular}

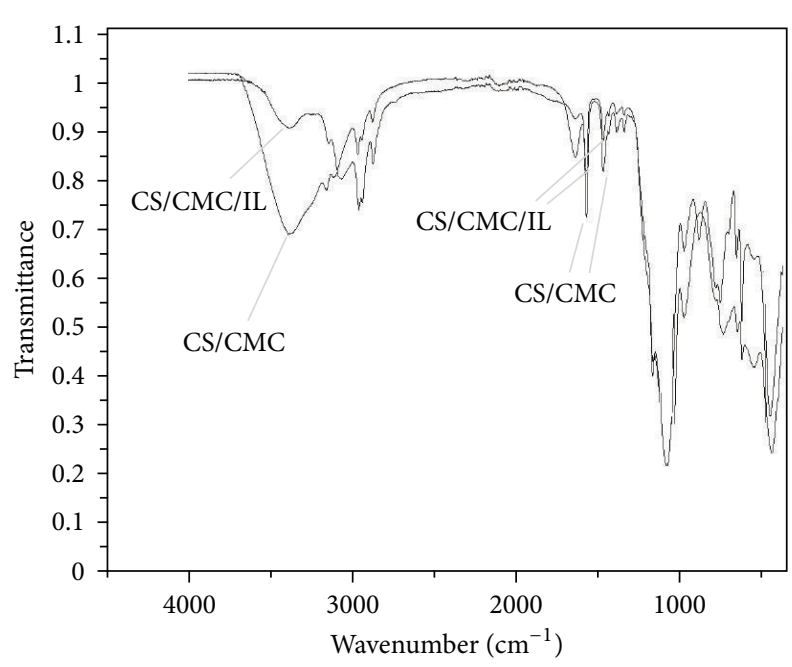

FIGURE 7: IR analysis of samples CS/CMC and CS/CMC/IL.

The antibacterial activities of CS/CMC/IL/Ag(0) polymeric membranes were investigated against gram-positive $S$. aureus and gram-negative $E$. coli that were explored by halo method. S. aureus exists on the body surface of mammals, and $E$. coli is a widespread intestinal parasite of mammals. The abilities of CS/CMC/IL/Ag(0) polymeric membranes to inhibit the growth of the test bacteria are shown in Table 4 and Figures 8 and 9. For the study, the control (CS/CMC/IL) occupied the left-hand side position in the agar plate and the sample CS/CMC/IL/Ag(0) occupied the right-hand side position. The concentration of $\operatorname{Ag}(0)$ nanoparticles in the membrane required to inactivate both bacteria can be low as $1 \mathrm{mg}$ per $5 \mathrm{~g}$ of CS/CMC/IL (compare entries 3 and 5, Table 4).

When the bacterial $S$. aureus was studied, the nanoparticles show a lower growth-inhibitory effect at the same concentration as compared with bacterial $E$. coli. These results suggest that the antimicrobial effects of $\operatorname{Ag}(0)$ nanoparticles might be associated with the characteristics of certain bacterial species.

The peptidoglycan layer of gram-negative bacteria (e.g., E. coli) is thinner than that of gram-positive bacteria (e.g., $S$. aureus) probably due $\operatorname{Ag}(0)$ nanoparticles can penetrate into the cell membrane of E. coli more easily and inhibit it more efficiently [35]. In order to use nanoparticles in various fields against microorganisms, it is essential to prepare nanoparticles with the high antimicrobial activities by controlling their size distributions and shapes. The CS/CMC/IL/Ag(0) polymeric membranes prepared in this study are homogeneous and stable (Figure 3 ). Therefore, the immobilization of the $\operatorname{Ag}(0)$ nanoparticles in the membranes and the ionic liquid is quite interesting since it prevents nanoparticle agglomeration and increased the contact area between $\operatorname{Ag}(0)$ nanoparticles and the microorganisms. In addition, the IL $\mathrm{BMI} \mathrm{BF}_{4}$ is hydrophilic and its viscosity is much higher than that of water [36]. Therefore, the CS/CMC/IL/Ag(0) ratio can be controlled for more efficient bacteria inactivation. Some hypotheses for the antimicrobial mechanism of $\operatorname{Ag}(0)$ have been reported $[37,38]$. In this respect, it was recently proposed, from studies on the inhibitory mechanism by electron spin resonance spectroscopy, that free radicals, derived from the surface of Ag nanoparticles, could attack the membrane lipids of the microorganisms leading to a breakdown of membrane function [36]. It is well known that 


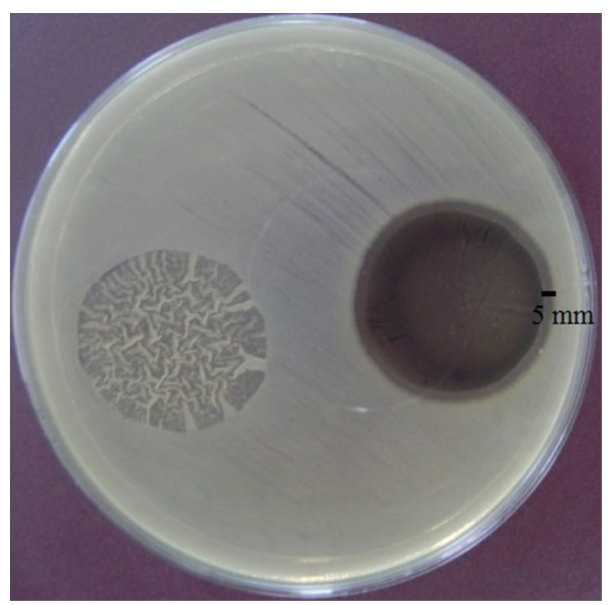

(a)

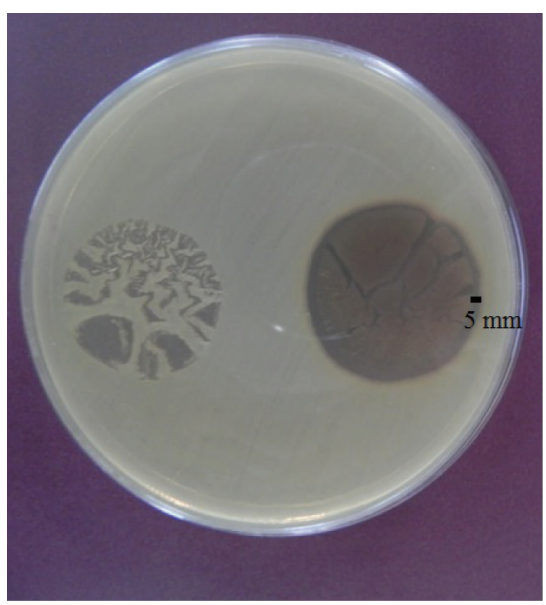

(b)

FIGURE 8: Antimicrobial activity of $5 \mathrm{mg}$ (a) and $10 \mathrm{mg}(\mathrm{b})$ of $\mathrm{Ag}(0)$ nanoparticles CS/CMC/IL films of the Escherichia coli.

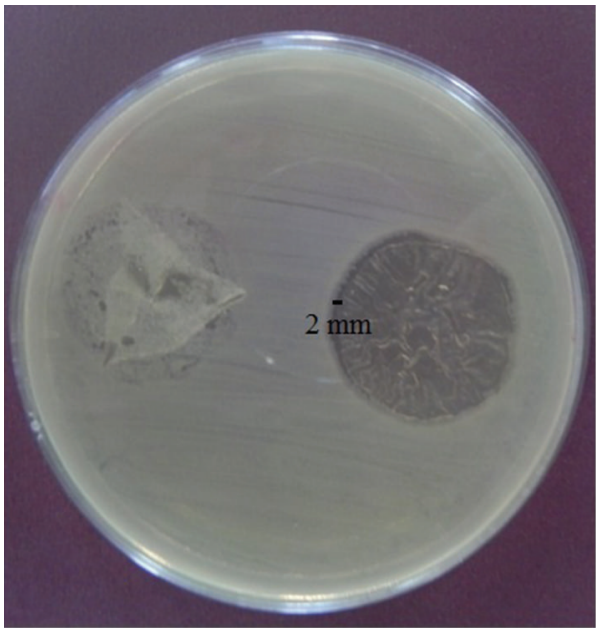

(a)

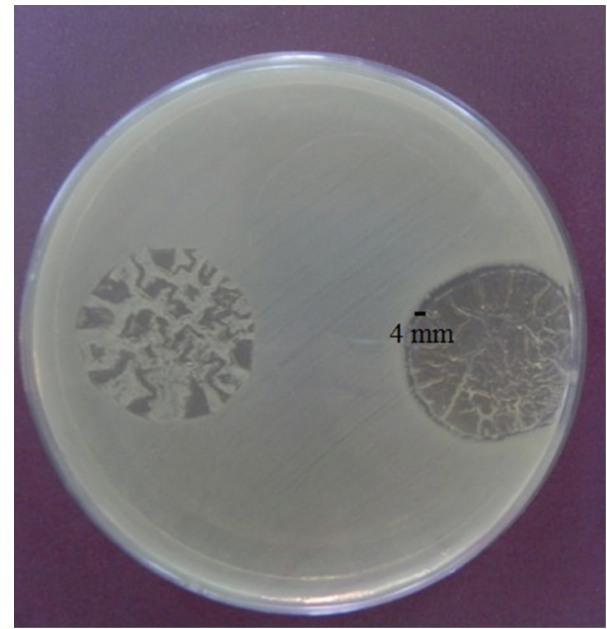

(b)

Figure 9: Antimicrobial activity (a) $5 \mathrm{mg}$ and (b) $10 \mathrm{mg}$ of $\mathrm{Ag}(0)$ nanoparticles CS/CMC/IL films of the Staphylococcus aureus.

smaller nanoparticles can penetrate into cell membranes and make the bacteria inactivate easily [39].

The higher antimicrobial activities observed in the $\operatorname{Ag}(0)$ samples are related to the smaller size of the nanoparticles used in this work (around $10 \mathrm{~nm}$ for $\operatorname{Ag}(0)$ as compared with the values reported in other works $[38,39])$. The inhibitory effects on the microorganisms in the surface of the polymer membrane that occur due the nanoparticles could adhere to the microorganism cell wall to destabilize it and alter cell permeability to be responsible for subsequent free radical-induced membrane damage [39]. The inhibitory effects of the $\mathrm{CS} / \mathrm{CMC} / \mathrm{IL} / \mathrm{Ag}(0)$ membranes are higher than those of the $\operatorname{Ag}(0)$ nanoparticles without the CS/CMC (see Table 4). This result is likely related to the higher dispersion of the nanoparticles in the membranes, that is, their lower agglomeration as compared with those freely "dissolved" in the ionic liquid. Therefore, the CS/CMC/IL/Ag(0) polymeric membranes prepared in this study are good candidates for use as controlled antimicrobial materials against E. coli and $S$. aureus bacteria, for pharmaceutical, medical, biological, and food applications.

\section{Conclusion}

The use of dispersed $\operatorname{Ag}(0)$ nanoparticles in $\mathrm{BMI}_{\mathrm{BF}} \mathrm{IL}$ in conjunction with chitosan/carboxymethylcellulose generated functionalized blend polymeric membrane presented good mechanical, thermal, and chemical stability. The introduction of the IL likely causes an increase in the distance between the polymeric macromolecules that results in higher flexibility, lower viscosity, and better formability of the chitosan/carboxymethylcellulose material. The $\mathrm{CS} / \mathrm{CMC} / \mathrm{IL} / \mathrm{Ag}(0)$ nanoparticles combination exhibits an excellent synergistic effect that demonstrated higher antimicrobial activity for S. aureus and E. coli bacteria. 


\section{Acknowledgments}

Thanks are due to the following Brazilian agencies: $\mathrm{CNPq}$ and CAPES for fellowships and partial financial support.

\section{References}

[1] P. K. Stoimenov, R. L. Klinger, G. L. Marchin, and K. J. Klabunde, "Metal oxide nanoparticles as bactericidal agents," Langmuir, vol. 18, no. 17, pp. 6679-6686, 2002.

[2] L. Balogh, D. R. Swanson, D. A. Tomalia, G. L. Hagnauer, and A. T. McManus, "Dendrimer-silver complexes and nanocomposites as antimicrobial agents," Nano Letters, vol. 1, no. 1, pp. $18-21,2001$.

[3] T. Kasuga, H. Kume, and Y. Abe, "Porous glass-ceramics with bacteriostatic properties in silver-containing titanium phosphates: control of release of silver ions from glass-ceramics into aqueous solution," Journal of the American Ceramic Society, vol. 80, no. 3, pp. 777-780, 1997.

[4] T. Kasuga, H. Kume, and Y. Abe, "Titanium phosphate glassceramics with silver ion exchangeability," Journal of the American Ceramic Society, vol. 82, no. 3, pp. 765-767, 1999.

[5] M. R. Yang, K. S. Chem, J. C. Rsai, C. C. Tseng, and S. F. Lin, "The antibacterial activities of hydrophilic-modified nonwoven PET,' Materials Science and Engineering C, vol. 20, no. 1-2, pp. 167-173, 2002.

[6] S. Y. Kwak, S. H. Kim, and S. S. Kim, "Hybrid organic/inorganic reverse osmosis (RO) membrane for bactericidal anti-fouling. 1. Preparation and characterization of $\mathrm{TiO}_{2}$ nanoparticle selfassembled aromatic polyamide thin-film-composite (TFC) membrane," Environmental Science \& Technology, vol. 35, no. 11, pp. 2388-2394, 2001.

[7] M. Kierans, A. M. Staines, H. Bennett, and G. M. Gadd, "Silver tolerance and accumulation in yeasts," Biology of Metals, vol. 4, no. 2, pp. 100-106, 1991.

[8] M. R. Ciriolo, P. Civitareale, M. T. Carri, A. De Martino, F. Galiazzo, and G. Rotilio, "Purification and characterization of Ag,Zn-superoxide dismutase from Saccharomyces cerevisiae exposed to silver," The Journal of Biological Chemistry, vol. 269, no. 41, pp. 25783-25787, 1994.

[9] B. Ding, E. Kimura, T. Sato, S. Fujita, and S. Shiratori, "Fabrication of blend biodegradable nanofibrous nonwoven mats via multi-jet electrospinning," Polymer, vol. 45, no. 6, pp. 1895-1902, 2004.

[10] A. Nagendran and D. R. Mohan, "Cellulose acetate and polyetherimide blend ultrafiltration membranes: II. Effect of additive," Polymers for Advanced Technologies, vol. 19, no. 1, pp. 24-35, 2008.

[11] K. J. Edgar, C. M. Buchanan, J. S. Debenham et al., "Advances in cellulose ester performance and application," Progress in Polymer Science, vol. 26, no. 9, pp. 1605-1688, 2001.

[12] G. Viswanathan, S. Murugesan, V. Pushparaj, O. Nalamasu, P. M. Ajayan, and R. J. Linhardt, "Preparation of biopolymer fibers by electrospinning from room temperature ionic liquids," Biomacromolecules, vol. 7, no. 2, pp. 415-418, 2006.

[13] M. Balci, A. Alli, B. Hazer, O. Güven, K. Cavicchi, and M. Cakmak, "Synthesis and characterization of novel comb-type amphiphilic graft copolymers containing polypropylene and polyethylene glycol," Polymer Bulletin, vol. 64, no. 7, pp. 691-705, 2010.
[14] O. H. Khan, T. L. Enno, and M. R. Del Bigio, "Brain damage in neonatal rats following kaolin induction of hydrocephalus," Experimental Neurology, vol. 200, no. 2, pp. 311-320, 2006.

[15] Y. Koike and M. Cakmak, "Atomic force microscopy observations on the structure development during uniaxial stretching of PP from partially molten state: effect of isotacticity," Macromolecules, vol. 37, no. 6, pp. 2171-2181, 2010.

[16] K. H. Lee, O. Ohsawa, K. Watanabe et al., "Electrospinning of syndiotactic polypropylene from a polymer solution at ambient temperatures," Macromolecules, vol. 42, no. 14, pp. 5215-5218, 2010.

[17] D. B. Hazer, D. Burcu, M. Mut et al., "The efficacy of silverembedded polypropylene-grafted polyethylene glycol-coated ventricular catheters on prevention of shunt catheter infection in rats," Child's Nervous System, vol. 28, no. 6, pp. 839-846, 2012.

[18] O. A. Kalayc1, F. B. Comert, B. Hazer, T. Atalay, K. A. Cavicchi, and M. Cakmak, "Synthesis, characterization, and antibacterial activity of metal nanoparticles embedded into amphiphilic comb-type graft copolymers," Polymer Bulletin, vol. 5, no. 3, pp. 215-226, 2010.

[19] O. A. El Seoud, A. Koschella, L. C. Fidale, S. Dorn, and T. Heinze, "Applications of ionic liquids in carbohydrate chemistry: a window of opportunities," Biomacromolecules, vol. 8, no. 9, pp. 2629-2647, 2007.

[20] P. Dash and R. W. J. Scott, "1-methylimidazole stabilization of gold nanoparticles in imidazolium ionic liquids," Chemical Communications, no. 7, pp. 812-814, 2009.

[21] C. C. Cassol, G. Ebeling, B. Ferrera, and J. Dupont, "A simple and practical method for the preparation and purity determination of halide-free imidazolium ionic liquids," Advanced Synthesis \& Catalysis, vol. 348, no. 1-2, pp. 243-248, 2006.

[22] J. R. Carbajal, Short Reference Guide of the Program Fullprof, version 3. 5., Ftp://Charybde.Saclay.Cea.Fr .

[23] E. P. Barrett, L. G. Joyner, and P. P. Halenda, “The determination of pore volume and area distributions in porous substances. I. Computations from nitrogen isotherms," Journal of the American Chemical Society, vol. 73, no. 1, pp. 373-380, 1951.

[24] S. Brunauer, "About some critics of the BET theory," Langmuir, vol. 3, no. 1, pp. 3-4, 1987.

[25] C. Peniche-Covas, W. Arguelles-Monal, and J. San Roman, "Sorption and desorption of water vapour by membranes of the polyelectrolyte complex of chitosan and carboxymethyl cellulose," Polymer International, vol. 38, no. 1, pp. 45-52, 1995.

[26] Z. J. Zhou, H. L. Chen, M. E. Liu, and Y. Zhang, "Pervaporation dehydration of alcohol with polyelectrolyte membrane," Chemical Journal of Chinese Universities, vol. 22, no. 7, pp. 1213-1215, 2001.

[27] V. M. Barragan, C. Rueda, and C. Ruizbauza, "On the fixed charge concentration and the water electroosmotic transport in a cellulose acetate membrane," Journal of Colloid and Interface Science, vol. 172, no. 2, pp. 361-367, 1995.

[28] L. N. Zhang, D. C. Zhou, H. Wang, and S. Y. Cheng, "Ion exchange membranes blended by cellulose cuoxam with alginate," Journal of Membrane Science, vol. 124, no. 2, pp. 195-201, 1997.

[29] A. Lali, A. N. A., R. John, and D. Thakrar, "Reversible precipitation of proteins on carboxymethyl cellulose," Process Biochemistry, vol. 35, no. 8, pp. 777-785, 2000.

[30] A. Bottino, G. Capannelli, A. Comite, A. Del Borghi, and R. R. Di Felice, "Catalytic ceramic membrane in a three-phase reactor for the competitive hydrogenation-isomerisation of 
methylenecyclohexane," Separation and Purification Technology, vol. 34, no. 1-3, pp. 239-245, 2004.

[31] G. Centi and S. Perathoner, "Novel catalyst design for multiphase reactions," Catalysis Today, vol. 79-80, pp. 3-13, 2003.

[32] J. Zaman and A. Chakma, "Inorganic membrane reactors," Journal of Membrane Science, vol. 92, no. 1, pp. 1-28, 1994.

[33] D. Fritsch and G. Bengtson, "Development of catalytically reactive porous membranes for the selective hydrogenation of sunflower oil," Catalysis Today, vol. 118, no. 1-2, pp. 121-127, 2006.

[34] E. A. Campos and Y. Gushikem, "Composite membrane of Niobium(V) oxide and cellulose acetate: preparation and characterization," Journal of Colloid and Interface Science, vol. 193, no. 1, pp. 121-126, 1997.

[35] K. Y. Yoon, J. H. yeon, J. H. Park, and J. Hwang, "Susceptibility constants of Escherichia coli and Bacillus subtilis to silver and copper nanoparticles," Science of The Total Environment, vol. 373, no. 2-3, pp. 572-575, 2007.

[36] A. E. Visser, W. M. Reichert, R. P. Swatloski, H. D. Willauer, J. G. Huddleston, and R. D. Rogers, "Characterization of hydrophilic and hydrophobic ionic liquids: alternatives to volatile organic compounds for liquid-liquid separations," Ionic Liquids, vol. 818, pp. 289-308, 2002.

[37] Y. J. Huang, D. Li, P. He, C. Y. Sun, M. J. Wang, and J. H. Li, "Semipermeable membrane embodying noble metal nanoparticles and its electrochemical behaviors," Journal of Electroanalytical Chemistry, vol. 579, no. 2, pp. 277-282, 2005.

[38] H. Y. Lee, H. K. Park, Y. M. Lee, K. Kim, and S. B. Park, "A practical procedure for producing silver nanocoated fabric and its antibacterial evaluation for biomedical applications," Chemical Communications, vol. 28, pp. 2959-2961, 2007.

[39] J. S. Kim, E. Kuk, K. N. Yu et al., "Antimicrobial effects of silver nanoparticles," Nanomedicine, vol. 3, no. 1, pp. 95-101, 2007. 

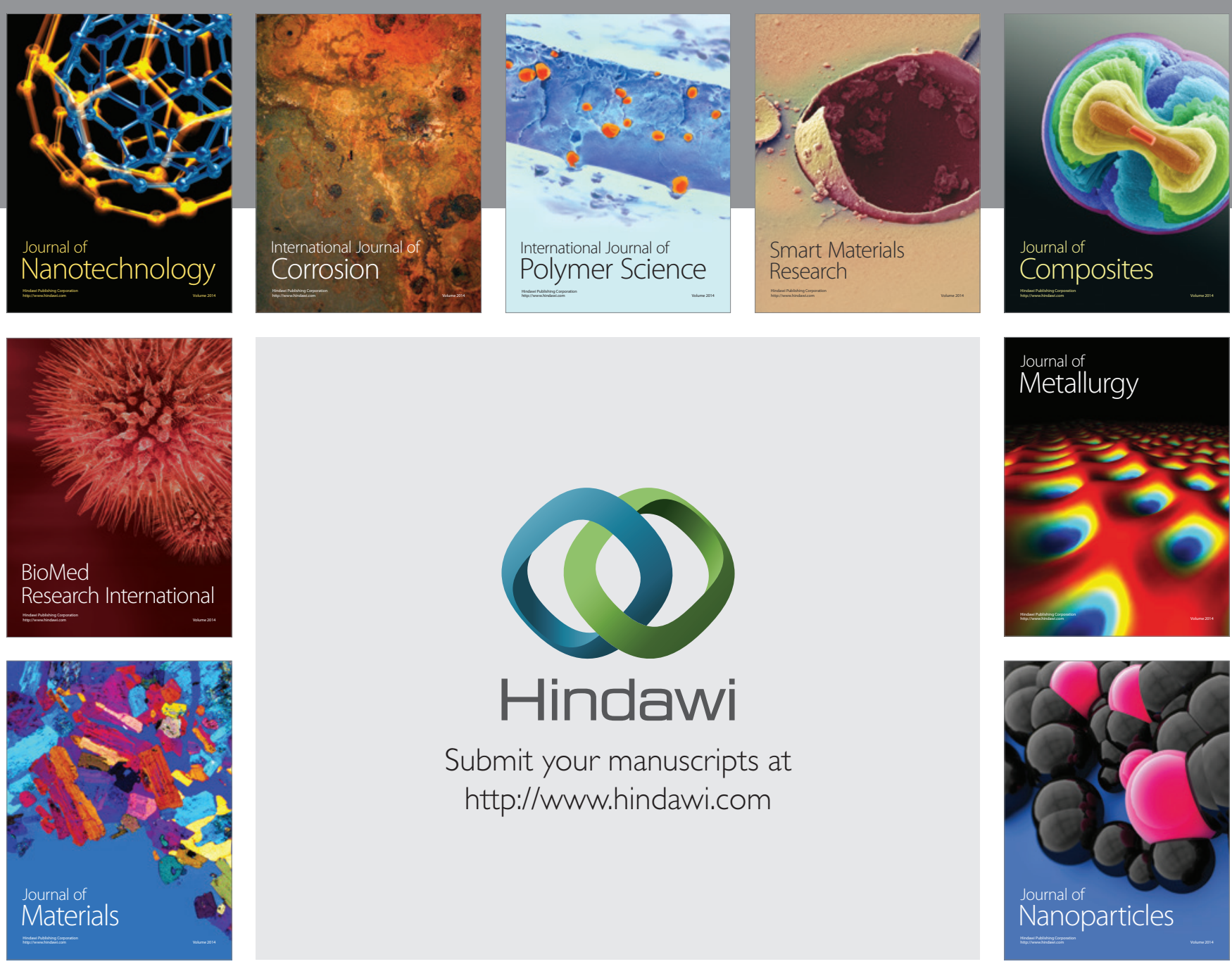

Submit your manuscripts at http://www.hindawi.com
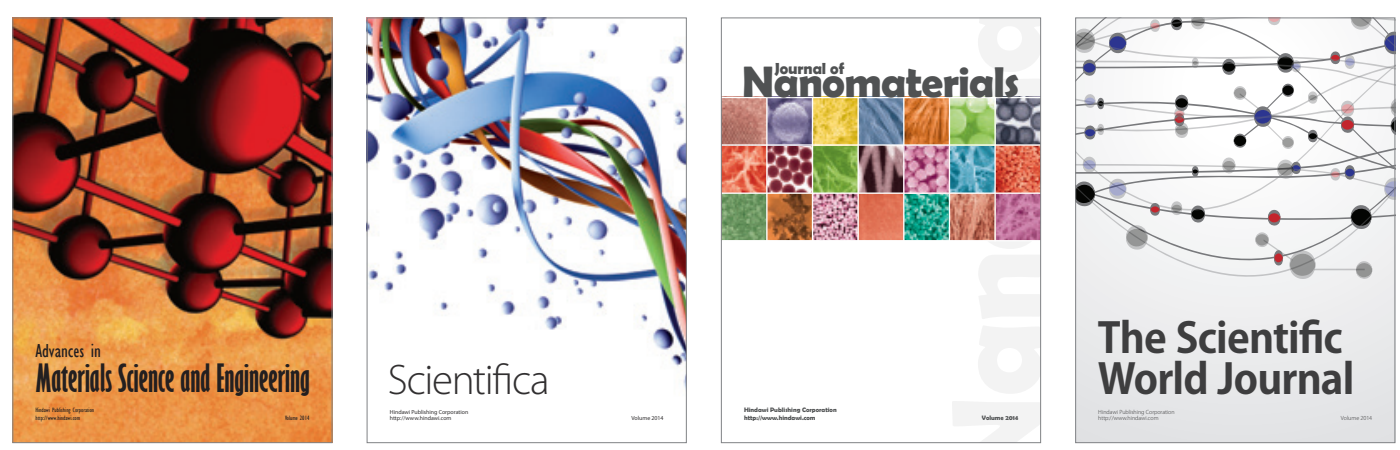

\section{The Scientific World Journal}
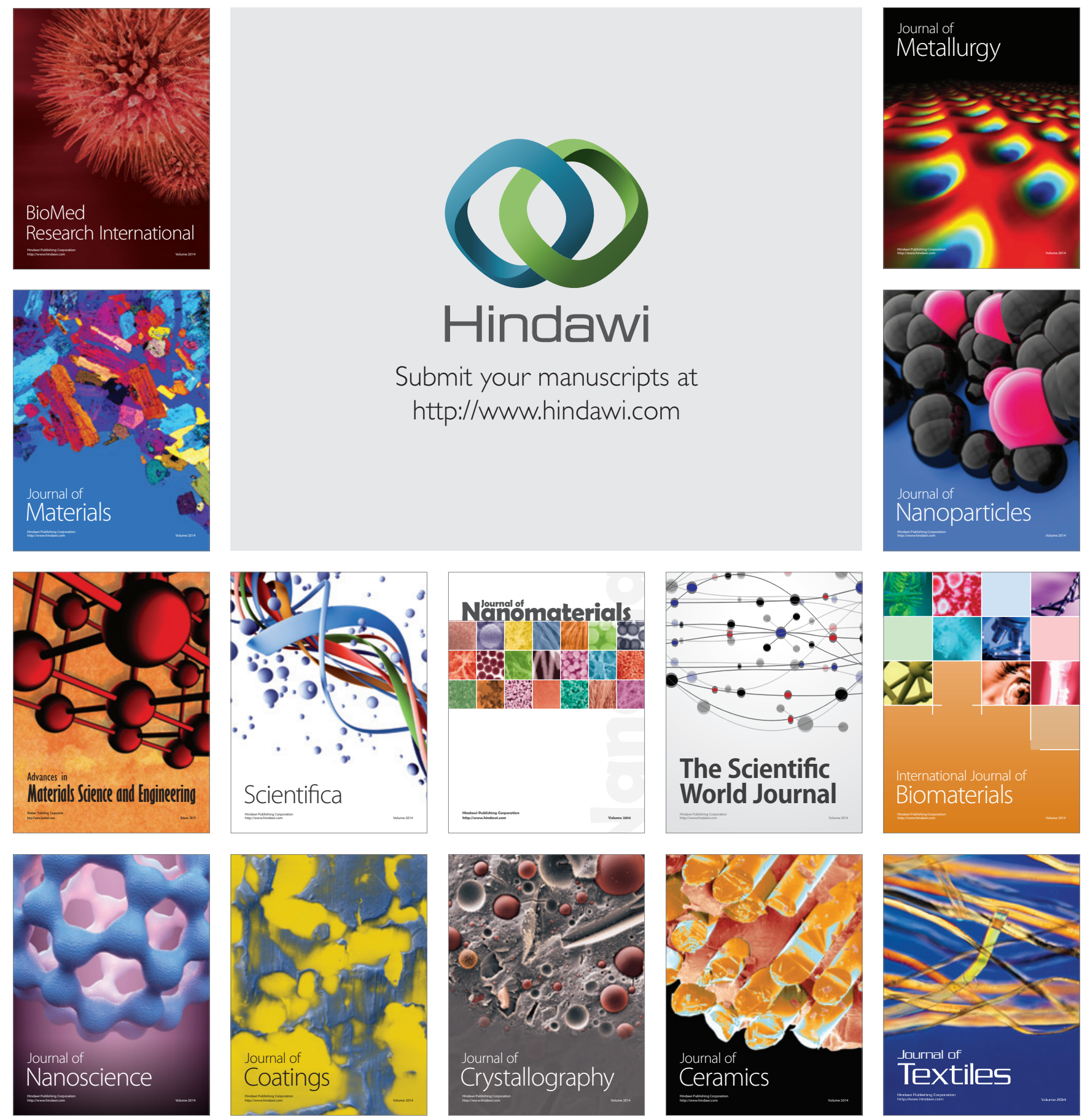